Jurnal Indonesia Sosial Teknologi: p-ISSN: 2723 - 6609

e-ISSN : 2745-5254

Vol. 2, No. 6 Juni 2021

\title{
PENGARUH MODAL SENDIRI TERHADAP SISA HASIL USAHA PADA KOPERASI PEGAWAI LISTRIK (KOPEL) PLTA PARAKANKONDANG KABUPATEN SUMEDANG
}

\author{
Ade Sobariah Hasanah \\ STIE STMY Majalengka \\ Email: ade.sobariah85@gmail.com
}

\section{Abstract}

This study aims to determine the effect of own capital on the Remaining Operating Income at the Electrical Employees Cooperative (Kopel) of the Parakankondang Hydroelectric Power Plant, Sumedang Regency. The method used is descriptive verification method. The research population is own capital data and SHU data from 1995 to 2019, the samples are own capital data and data on the number of SHU Kopel Parakankondang for the last five years (2015 - 2019) taken by purposive sampling technique. The results of the simple linear regression test obtained the equation $=52.791 .501 .860+0.03 \mathrm{X}$; This means that every increase in the amount of own capital issued so far has resulted in an increase in the number of SHU. From the results of the correlation test, the value of $r=0.987$ means that the amount of own capital has a very strong relationship with the number of SHU. The results of the determination test showed that the number of SHU which was influenced by the amount of own capital was $97.40 \%$, while the remaining $2.60 \%$ was influenced by other factors not examined. Based on the results of hypothesis testing using the t-test, the $t$-value $i s_{\text {coum }} 10.512$ and the $t$ - -able $_{\text {e }}$ at $a=0.05$ and $d k=3$ is 2.353 so that $t$-count $>t$ table; means Ho is rejected or Ha is accepted. It can be concluded that the capital itself has a positive and significant effect on SHU in the Electrical Employees Cooperative (Kopel) of the Parakankondang Hydroelectric Power Plant, Sumedang Regency

Keyword : owner's equity; remaining operating results.

\section{Abstrak}

Koperasi Pegawai Listrik (Kopel) Parakankondang berada dilingkungan PLTA Parakankondang dengan tujuan untuk mensejahterakan anggotanya. Dalam menjalankan kegiatannya, koperasi memerlukan modal guna menjaga dan meningkatkan usaha koperasi, sehingga dapat menghasilkan Sisa Hasil Usaha. Penelitian ini bertujuan untuk mengetahui pengaruh modal sendiri terhadap Sisa Hasil Usaha pada Koperasi Pegawai Listrik (Kopel) PLTA Parakankondang Kabupaten Sumedang. Metode yang digunakan adalah metode deskriptif verifikatif. Populasi penelitian yaitu data modal sendiri dan data SHU dari tahun 1995 sampai dengan tahun 2019, sampelnya adalah data modal sendiri dan data jumlah SHU Kopel Parakankondang selama lima tahun terakhir (2015 - 2019) yang diambil dengan teknik purposive sampling. Hasil uji regresi linear sederhana diperoleh persamaan $\hat{Y}=52.791 .501,860+0,03 \mathrm{X}$; artinya setiap kenaikan jumlah modal sendiri yang dikeluarkan selama ini mengakibatkan kenaikan jumlah SHU. Dari hasil 
uji korelasi diperoleh nilai $\mathrm{r}=0,987$ artinya jumlah modal sendiri mempunyai hubungan yang sangat kuat dengan jumlah SHU. Hasil uji determinasi menunjukkan bahwa jumlah SHU yang dipengaruhi oleh jumlah modal sendiri adalah sebesar $97,40 \%$, sedangkan sisanya sebesar $2,60 \%$ dipengaruhi oleh faktor lain yang tidak diteliti. Berdasarkan hasil pengujian hipotesis menggunakan uji $\mathrm{t}$, diperoleh nilai $t_{\text {hitung }}$ sebesar 10,512 dan $t_{\text {tabel }}$ pada $\alpha=0,05$ dan $\mathrm{dk}=3$ adalah 2,353 sehingga $t_{\text {hitung }}$ $>\mathrm{t}_{\text {tabel}}$; artinya Ho ditolak atau Ha diterima. Dapat disimpulkan bahwa modal sendiri berpengaruh positif dan signifikan terhadap SHU pada Koperasi Pegawai Listri (Kopel) PLTA Parakankondang Kabupaten Sumedang.

Kata kunci: modal sendiri; sisa hasil usaha.

\section{Pendahuluan}

Dalam Pasal 1 UU No.25 Tahun 1992 mengatakan bahwa: "Koperasi adalah badan usaha yang beranggotakan orang seorang atau badan hukum koperasi dengan melandaskan kegiatannya berdasarkan prinsip koperasi sekaligus sebagai gerakan ekonomi rakyat yang berdasarkan atas asas kekeluargaan. Sebagai badan usaha pada hakikatnya koperasi memiliki karakteristik dan tujuan yang tidak jauh berbeda dengan badan usaha lainnya. Namun bukan berarti antara koperasi dengan badan usaha lain memiliki kesamaan dalam segala hal, karena koperasi tetap memiliki karakteristik tersendiri yang tidak dimiliki oleh badan usaha lain. Kesamaan yang sangat jelas adalah sama-sama memperoleh keuntungan. Akan tetapi koperasi memiliki ciri yang khas yaitu anggota koperasi memiliki "identitas ganda" (dual identity), sebagai pemilik sekaligus sebagai pelanggan atau pengguna koperasi. Sebagai pemilik, maka anggota diharapkan dapat memberi kontribusi pada koperasi baik berupa modal, pelaksanaan program serta pengawasan dan kemajuan koperasi. Sebagai pelanggan, anggota dapat memanfaatkan berbagai pelayanan usaha koperasi. Istilah keuntungan pada koperasi dirasakan kurang tepat karena pada dasarnya kegiatan usaha di dalam koperasi bukan semata-mata mencari keuntungan tetapi berorientasi pada manfaat. Koperasi pada dasarnya dikelola dengan tujuan untuk mensejahterakan anggotanya. Koperasi diharapkan dapat mengelola kegiatan usahanya demi kelangsungan hidup koperasi yang bersangkutan. Melihat fenomena tersebut maka koperasi memerlukan modal dalam menjaga dan meningkatkan usaha koperasi. Sehingga di akhir periode usahanya, koperasi diharapkan dapat menghasilkan Sisa Hasil Usaha.

Modal koperasi salah satunya terdiri dari modal sendiri. Modal sendiri dapat berasal dari: simpanan pokok, simpanan wajib, dana cadangan dan hibah. Menurut (Riyanto, 2010) beranggapan bahwa pembelanjaaan yang sehat itu pertama-tama dibangun atas dasar modal sendiri, yaitu modal tahan resiko. Sedangkan (Ign Sukamdiyo \& DASUKI, 1996) berpendapat bahwa dengan pengelolaan modal sendiri yang baik diharapkan akan memberikan manfaat yang dapat mendatangkan keuntungan (Sisa Hasil Usaha) bagi koperasi. Jika modal sendiri naik maka Sisa Hasil Usaha (SHU) yang diperoleh akan naik juga. 
Koperasi Pegawai Listrik (Kopel) Parakankondang lahir dilingkungan PLTA Parakankondang Kabupaten Sumedang, hal ini didorong oleh keinginan bersama dilingkungan para pegawai untuk mendirikan koperasi. Dari tahun 1995 pertama koperasi ini berdiri, koperasi terus menampakkan perkembangan yang signifikan. Hal ini tidak terlepas dari peran serta anggota koperasi yang memberikan perannya dalam memenuhi kewajibannya salah satunya modal yang anggota tanamkan lewat simpanan anggota, juga dana cadangan dan hibah yang dimiliki koperasi Pegawai Listrik Parakankondang. Sehingga dengan bertambahnya modal koperasi diharapkan akan bertambah juga Sisa Hasil Usahanya. Hal ini sejalan dengan penelitian empiris yang telah dilakukan (Albana, 2015), (Bustani \& Firdaus, 2020), serta (Sari \& Rivandi, 2018) yang menyatakan bahwa modal sendiri berpengaruh positif dan signifikan terhadap SHU pada koperasi.

Bertitik tolak pada latar belakang tersebut di atas, maka penelitian ini disusun untuk mengetahui pengaruh modal sendiri terhadap Sisa Hasil Usaha pada koperasi Pegawai Listrik (Kopel) PLTA Parakankondang Kabupaten Sumedang. Adapun tujuan dari penelitian ini adalah: 1) untuk mengetahui besarnya modal sendiri yang ditetapkan oleh Koperasi Pegawai Listrik (Kopel) PLTA Parakankondang Kabupaten Sumedang. 2) untuk mengetahui besarnya jumlah SHU pada Koperasi Pegawai Listrik (Kopel) PLTA Parakankondang Kabupaten Sumedang. 3) untuk mengetahui besarnya pengaruh modal sendiri terhadap jumlah SHU pada Koperasi Pegawai Listrik (Kopel) PLTA Parakankondang Kabupaten Sumedang.

\section{Metode Penelitian}

Metode yang digunakan dalam penelitian ini adalah metode deskriptif verifikatif. Menurut (Sugiyono, 2017) "Metode deskriptif adalah metode yang digunakan untuk menggambarkan atau menganalisis suatu hasil penelitian tetapi tidak digunakan untuk membuat kesimpulan yang lebih luas, sedangkan metode verifikatif adalah suatu metode penelitian yang bertujuan mengetahui hubungan kausalitas antara variabel melalui suatu pengujian melalui suatu perhitungan statistik didapat hasil pembuktian yang menunjukkan hipotesis ditolak atau diterima. Untuk mengetahui hubungan yang terjadi antara modal sendiri dan SHU, maka data diolah menggunakan uji regresi linear sederhana, uji korelasi, uji determinasi. (Narimawati, 2008) menjelaskan bahwa uji regresi digunakan untuk membuktikan sejauhmana hubungan pengaruh variabel bebas terhadap variabel terikat, uji korelasi bertujuan untuk mengukur hubungan fungsional antar variabel bebas dan terikat, sedangkan uji determinasi bertujuan untuk mengetahui seberapa besar pengaruh antar variabel bebas dan variabel terikat. Untuk menguji hipotesis dilakukan dengan membandingkan nilai dengan membandingkan t hitung dengan t tabel. Analisa data dan pengujian hipotesis ini dilakukan dengan bantuan software SPSS versi 23.

\section{Hasil dan Pembahasan}

\section{Modal Sendiri}

Menurut Undang-undang nomor 25 tahun 1992 tentang perkoperasian, modal koperasi terdiri atas modal sendiri dan modal pinjaman Kementrian Koperasi dan 
Usaha Kecil dan Menengah Republik Indonesia, 2020). Di sisi lain modal sendiri menurut (Mardiyatmo, 2008) adalah modal yang diperoleh dari pemilik usaha sendiri. Modal sendiri dalam koperasi bersumber dari: simpanan pokok, simpanan wajib, dana cadangan, dan hibah (I. G. N. Sukamdiyo, 1997).

Keberadaan modal sendiri diterapkan sebagai bahan informasi mengenai beberapa besar jumlah dana yang tertanam dan mengetahui rata-rata pertumbuhan setiap periodenya. Daftar modal sendiri pada Koperasi Pegawai Listrik (Kopel) Parakankondang periode 2015-2019 dapat dilihat pada tabel berikut:

Tabel 1

Modal Sendiri Tahun 2015 - 2019

Koperasi Pegawai Listrik Parakankondang Kab Sumedang

\begin{tabular}{llll}
\hline Tahun & SHU & \multicolumn{2}{c}{ Fluktuasi } \\
\cline { 3 - 4 } & & Rp & $\%$ \\
\hline 2015 & 848.066 .915 & & \\
\hline 2016 & 893.665 .485 & 45.598 .570 & 0,05 \\
\hline 2017 & 928.219 .640 & 34.554 .155 & 0,04 \\
\hline 2018 & 949.052 .956 & 20.833 .316 & 0,02 \\
\hline 2019 & 975.037 .227 & 25.984 .271 & 0,03
\end{tabular}

Sumber: Koperasi Pegawai Listrik (Kopel) PLTA Parakankondang, 2021

Berdasarkan tabel 1 dapat ditarik kesimpulan bahwa tren modal koperasi mengalami penurunan dan kenaikan. Penurunan modal koperasi di sebabkan oleh menurunnya partisipasi anggota dan kepasifan anggota khususnya anggota yang sudah lama bergabung di koperasi kurang aktif dalam menginvestasikan dananya. Sedangkan kenaikan tren modal sendiri disebabkan oleh anggota koperasi tetap loyal dalam memberikan partisipasi pada koperasi dan pihak pengurus koperasi selalu berusaha untuk memberikan pelayanan yang baik pada anggota koperasi. Apabila koperasi dapat mengelola modal sendiri dengan baik, maka tidak menutup kemungkinan kopersi tersebut dapat menjalan usahanya dengan baik juga (Apriyanti, 2013). Modal koperasi yang terbaik adalah modal sendiri karena modal sendiri yang dihimpun dari anggota tidak dibebani bunga dan manfaat yang diterima anggota lebih besar dibandingkan menggunakan modal pinjaman. Hal ini sejalan dengan pendapat (Andriani, 2017) bahwa manajemen risiko yang baik bagi koperasi adalah menggunakan modal sendiri. Modal koperasi ini digunakan semaksimal mungkin untuk mewujudkan kesejahteraan dan meningkatkan ekonomi anggotanya (Rohmansyah \& Sudarijati, 2017).

\section{SHU Pada Koperasi Pegawai Listrik (Kopel) Parakankondang}

Sisa Hasil Usaha (SHU) adalah pendapatan koperasi yang diperoleh dalam waktu satu tahun buku dikurangi dengan biaya, penyusutan dan kewajiban lainnya termasuk pajak dalam buku yang bersangkutan (UU No. 25 Tahun 1992 Pasal 1 \& 2). Usaha yang dijalankan oleh koperasi diarahkan untuk menunjang kesejahteraan anggotanya. Perolehan Sisa Hasil Usaha akan terlihat pada data laporan keuangan dalam laporan tahunan koperasi pada tutup buku akhir tahun. Dimana SHU akan memberikan gambaran 
hasil yang telah dicapai oleh koperasi selama periode tertentu dalam satu tahun buku. SHU yang maksimal merupakan salah satu faktor keberhasilan koperasi.

Adapun hasil analisis SHU pada Koperasi Pegawai Listrik (Kopel) Parakankondang Kab. Sumedang tahun 2015-2019 per tahunnya dapat dilihat pada tabel di bawah ini:

Tabel 2

Sisa Hasil Usaha Tahun 2015 - 2019 Koperasi Pegawai Listrik Parakankondang Kab Sumedang

\begin{tabular}{llcl}
\hline Tahun & SHU & \multicolumn{2}{c}{ Fluktuasi } \\
\cline { 3 - 4 } & & Rp & $\%$ \\
\hline 2015 & 5.269 .480 .000 & & \\
\hline 2016 & 5.478 .462 .000 & 2.136 .585 & 0,03 \\
\hline 2017 & 6.278 .920 .000 & 537.637 & 0,01 \\
\hline 2018 & 6.564 .350 .000 & 733.711 & 0,01 \\
\hline 2019 & 7.125 .769 .000 & 1.229 .499 & 0,01 \\
\hline
\end{tabular}

Sumber: Koperasi Pegawai Listrik (Kopel) PLTA Parakankondang, 2021

Berdasarkan tabel 2 dapat ditarik kesimpulan bahwa jumlah SHU dari 2015-2019 mengalami kenaikan dan juga penurunan. Kenaikan jumlah SHU disebabkan bertambahnya partisipasi anggota koperasi sehingga aktivitas koperasi bertambah dan hal ini mempengaruhi pada bertambahnya laju modal koperasi yang mengakibatkan SHU semakin bertambah. Sedangkan penurunan jumlah SHU salah satunya disebabkan karena adanya kenaikan dalam biaya operasional pada Koperasi Pegawai Listrik (Kopel) Parakankondang. SHU menggambarkan keseluruhan pendapatan koperasi yang dikurangi seluruh total biaya dalam satu periode (Pradana, 2019). Untuk meraih SHU yang maksimal, faktor yang sangat penting dalam tata kelola koperasi adalah konsistensi keuntungan yang cenderung meningkat (Suteja, Sujana, \& Nuridja, 2016). Hal ini sejalan dengan pendapat Ningsih, (Ningsih, Isnaini, Handayani, \& Neneng, 2017) bahwa dengan adanya konsistensi SHU maka kelangsungan operasional koperasi menjadi lebih baik. Sehingga semakin meningkat SHU maka kesejahteraan anggotapun akan mudah dicapai.

\section{Pengaruh Modal Sendiri Terhadap SHU Pada Koperasi Pegawai Listrik (Kopel) PLTA Parakankondang Kabupaten Sumedang}

Upaya peningkatan modal sendiri diyakini dapat berdampak pada SHU Kopel PLTA Parakankondang. Untuk mencapai hal tersebut diperlukan suatu strategi yang tepat yang harus dilakukan oleh koperasi. Berkaitan dengan hal tersebut, pada bagian ini penulis akan melakukan analisa mengenai pengaruh modal sendiri terhadap SHU pada Koperasi Pegawai Listrik, dan digunakan alat uji sebagai berikut:

a. Uji Regresi Linear Sederhana

Uji ini digunakan untuk mengetahui hubungan fungsional antara modal sendiri dengan SHU. Hasil analisa uji regresi sederhana disajikan dalam tabel 3 di bawah ini: 
Tabel 3

Hasil Analisis Regresi Linear Sederhana

Coefficients $^{\mathrm{a}}$

\begin{tabular}{|c|c|c|c|c|c|c|}
\hline \multirow{2}{*}{\multicolumn{2}{|c|}{ Model }} & \multicolumn{5}{|c|}{ Standardized } \\
\hline & & B & Std. Error & $\frac{\text { Coefficients }}{\text { Beta }}$ & $\mathrm{t}$ & Sig. \\
\hline 1 & (Constant) & 52791501,860 & 2993367,091 & & 17,636 &, 000 \\
\hline & Modal Sendiri & ,034 & ,003 & 987 & 10,512 & ,002 \\
\hline
\end{tabular}

Sumber: Hasil pengolahan data dengan SPSS versi 23

Berdasarkan tabel 3, diperoleh nilai koefisien regresi $\mathrm{a}=52791501,860 \mathrm{dan} \mathrm{b}$ $=0,34$ sehingga diperoleh persamaan regresi $\hat{Y}=52791501,860+0,034$ X. Dari persamaan tersebut, dapat dijelaskan bahwa setiap kenaikan modal sendiri yang pada koperasi selama ini mengakibatkan kenaikan jumlah SHU sebesar 0,034 X.

b. Uji Korelasi

Uji korelasi digunakan untuk mengetahui keeratan hubungan antara modal sendiri dengan SHU. Hasil analisa uji korelasi disajikan dalam tabel 4 di bawah ini:

Tabel 4

Hasil Analisis Korelasi

\begin{tabular}{|c|c|c|c|}
\hline \multicolumn{4}{|c|}{ Correlations } \\
\hline & & $\begin{array}{l}\text { Modal } \\
\text { Sendiri }\end{array}$ & SHU \\
\hline \multirow[t]{3}{*}{$\begin{array}{l}\text { Modal } \\
\text { Sendiri }\end{array}$} & $\begin{array}{l}\text { Pearson } \\
\text { Correlation }\end{array}$ & 1 &, $987^{* *}$ \\
\hline & Sig. (2-tailed) & &, 002 \\
\hline & $\mathrm{N}$ & 5 & 5 \\
\hline \multirow[t]{3}{*}{ SHU } & $\begin{array}{l}\text { Pearson } \\
\text { Correlation }\end{array}$ &, $987^{* *}$ & 1 \\
\hline & Sig. (2-tailed) & ,002 & \\
\hline & $\mathrm{N}$ & 5 & 5 \\
\hline
\end{tabular}

**. Correlation is significant at the 0.01 level (2-tailed).

Sumber: Hasil pengolahan data dengan SPSS versi 23

Berdasarkan tabel 4, diperoleh nilai korelasi (r) sebesar 0,987. Dengan mengacu pada pedoman interpretasi nilai korelasi (r) sebesar 0,987 berarti bahwa jumlah modal sendiri pada Koperasi Pegawai Listrik (Kopel) PLTA Parakankondang mempunyai hubungan yang sangat kuat dengan Sisa Hasil Usaha.

c. Uji Koefisien Determinasi 
Uji determinasi digunakan untuk mengetahi besarnya persentase pengaruh modal sendiri terhadap SHU. Hasil analisa uji determinasi disajikan dalam tabel 6.

Tabel 5

Hasil Analisis Koefisien Determinasi

\begin{tabular}{lcccc}
\hline \multicolumn{5}{c}{ Model Summary } \\
\hline Model & $\mathrm{R}$ & $\mathrm{R}$ Square & $\begin{array}{c}\text { Adjusted R } \\
\text { Square }\end{array}$ & $\begin{array}{c}\text { Std. Error of } \\
\text { the Estimate }\end{array}$ \\
\hline 1 &, $987^{\mathrm{a}}$ &, 974 &, 965 & 322164,616 \\
\hline \multicolumn{4}{l}{ a. Predictors: (Constant), Modal Sendiri } \\
\hline Sumber: Hasil pengolahan data dengan SPSS versi 23
\end{tabular}

Berdasarkan data pada tabel 5, besarnya koefisien determinasi adalah 97,40\%, berarti jumlah Sisa Hasil Usaha yang dipengaruhi oleh modal sendiri adalah sebesar $97,40 \%$. Sedangkan sisanya sebesar 2,60\% dipengaruhi oleh variabel atau faktor lain yang tidak diteliti.

d. Uji Hipotesis

Untuk lebih memperjelas hasil pengujian pengaruh modal sendiri (variabel $\mathrm{X}$ ) terhadap SHU (variabel Y), perlu adanya pengujian lebih lanjut untuk menguji hipotesis yang telah dikemukakan sebelumnya. Hasil dari uji hipotesis disajikan dalam tabel 6 yaitu:

Tabel 6

Hasil Uji Hipotesis

\begin{tabular}{|c|c|c|c|c|c|c|}
\hline \multicolumn{7}{|c|}{ Coefficients $^{\mathrm{a}}$} \\
\hline & & & & Standardized & & \\
\hline & & Unstandardize & I Coefficients & Coefficients & & \\
\hline \multicolumn{2}{|c|}{ Model } & B & Std. Error & Beta & $\mathrm{t}$ & Sig. \\
\hline \multirow[t]{2}{*}{1} & (Constant) & $\begin{array}{r}52791501,86 \\
0\end{array}$ & 2993367,091 & & 17,636 & ,000 \\
\hline & Modal Sendiri & ,034 & 003 & 987 & 10,512 &, 002 \\
\hline
\end{tabular}

a. Dependent Variable: SHU

Sumber: Hasil pengolahan data dengan SPSS versi 23

Dari hasil perhitungan pada tabel 6 , diketahui $t_{\text {hitung }}$ sebesar 10,512 dan $t_{\text {tabel }}$ pada $\alpha=0,05$ dan $\mathrm{dk}=3$ adalah 2,353; artinya Ho ditolak atau Ha diterima. Hal ini berarti bahwa modal sendiri berpengaruh positif dan signifikan terhadap Sisa Hasil Usaha pada Koperasi Pegawai Listrik (Kopel) PLTA Parakankondang Kabupaten Sumedang. Hasil penelitian ini sejalan dengan hasil penelitian Martowinangun \& Aoliyani, 2019) yang menjelaskan bahwa terdapat hubungan antara modal sendiri dengan sisa hasil usaha. Sedangkan (Bustani \& Firdaus, 2020) menjelaskan bahwa terdapat pengaruh signifikan dan positif antara modal sendiri terhadap sisa hasil 
usaha. Sehingga dapat disimpulkan bahwa besar kecilnya modal sendiri pada koperasi sangat mempengaruhi jumlah Sisa Hasil Usaha pada suatu koperasi.

\section{Kesimpulan}

1. Berdasarkan perolehan data mengenai modal sendiri, dapat diketahui bahwa modal sendiri pada Koperasi pegawai listrik (Koperl) PLTA Parakankondang dari tahun 2015 sampai 2019 mengalami penurunan dan kenaikan. Penurunan modal sendiri Hal ini disebabkan karena berkurangnya modal yang ditanamkan anggota pada koperasi, sedangkan kenaikan modal sendiri disebabkan oleh pemberian layanan yang semakin baik dari koperasi yang bersangkutan.

2. Dalam hal jumlah sisa hasil usaha, dapat diketahui bahwa jumlah SHU mengalami kenaikan dan penurunan. Kenaikan SHU disebabakan oleh bertambahnya partisipasi anggota koperasi, sedangkan penurunan SHU disebabkan oleh naiknya biaya operasional koperasi.

3. Hasil uji hipotesis menunjukkan bahwa modal sendiri berpengaruh positif dan signifikan terhadap sisa hasil usaha pada Koperasi Pegawai Listri (Kopel) PLTA Parakankondang Kabupaten Sumedang. 
Pengaruh Modal Sendiri Terhadap Sisa Hasil Usaha pada Koperasi Pegawai Listrik (Kopel) Plta Parakankondang Kabupaten Sumedang

\section{Bibliography}

Albana, Isna Farah. (2015). Pengaruh Modal Sendiri dan Current Ratio terhadap Sisa Hasil Usaha (SHU) di KPRI Kota Semarang Tahun 2013. UNIVERSITAS NEGERI SEMARANG.

Andriani, A. (2017). Analisis Perkembangan Modal dan Pendapatan Usaha terhadap Sisa Hasil Usaha pada Koperasi Tani (KOPTAN) Jasa Tirta Kabupaten Tulungagung. Jurnal Ekonomi, 1-12.

Apriyanti, Alit Nur. (2013). ANALISIS PERKEMBANGAN MODAL DAN PENDAPATAN USAHA KOPERASI DALAM RANGKA MENINGKATKAN SISA HASIL USAHA DI KPRI HARAPAN MOJOKERTO. Jurnal Pendidikan Ekonomi (JUPE), 1(3).

Bustani, Bustani, \& Firdaus, Firdaus. (2020). Pengaruh Modal Sendiri dan Volume Usaha terhadap Sisa Hasil Usaha (SHU) pada Koperasi Karyawan Siti Khadijah RS Islam Banjarmasin. Jurnal Maksipreneur: Manajemen, Koperasi, Dan Entrepreneurship, 10(1), 31-47.

Indonesia, Kementrian Koperasi dan Usaha Kecil dan Menengah Republik. (2020). $\underline{\text { Kementrian Koperasi dan Usaha Kecil dan Menengah Republik Indonesia. }}$

Mardiyatmo. (2008). Kewirausahaan. Surakarta.

Martowinangun, Kasino, \& Aoliyani, Widdi. (2019). Pengaruh Modal Sendiri Terhadap Sisa Hasil Usaha Pada Primer Koperasi XXX. Jurnal Co Management, 1(3), 231245.

Narimawati, Umi. (2008). Metodologi penelitian kualitatif dan kuantitatif, teori dan aplikasi. Bandung: Agung Media, 9.

Ningsih, Nurfitria, Isnaini, Fatmawati, Handayani, Nurlia, \& Neneng, Neneng. (2017). Pengembangan Sistem Perhitungan SHU (Sisa Hasil Usaha) untuk Meningkatkan Penghasilan Anggota pada Koperasi Manunggal Karya. Jurnal Tekno Kompak, 11(1), 10-13.

Pradana, Reza Septian. (2019). Strategi Peningkatan Perolehan Sisa Hasil Usaha (SHU) Koperasi di Kota Banda Aceh. Jurnal Ekonomi-Qu, 9(1).

Riyanto, Bambang. (2010). Dasar-dasar Pembelanjaan Perusahaan Edisi 4 Cetakan 10. Yogyakarta: BPFE-Yogyakarta.

Rohmansyah, Tria, \& Sudarijati, Sudarijati. (2017). Pengaruh modal sendiri dan modal pinjaman terhadap sisa hasil usaha (SHU) koperasi Kota Sukabumi. Jurnal Visionida, 3(2), 55-67.

Sari, Miky Pusvita, \& Rivandi, Muhammad. (2018). Pengaruh Modal Sendiri dan Modal 
Ade Sobariah Hasanah

Pinjaman terhadap Perolehan Sisa Hasil Usaha Pada Koperasi di Kota Padang.

Sugiyono. (2017). Metode Penelitian Kuantitatif, Kualitatif, dan R\&D. Bandung.

Sukamdiyo, I. G. N. (1997). Manajemen Koperasi Pasca UU 25/1992. Erlangga, Jakarta.

Sukamdiyo, Ign, \& DASUKI, Alex. (1996). Manajemen Koperasi: Pasca UU No. 25 Tahun 1992.

Suteja, Gede Praba, Sujana, I. Nyoman, \& Nuridja, I. Made. (2016). Pengaruh Jumlah Modal Sendiri Dan Jumlah Modal Pinjaman Terhadap Perolehan Sisa Hasil Usaha Pada Kpn Praja Mukti Kantor Bupati Buleleng Tahun 2006-2015. Jurnal Pendidikan Ekonomi Undiksha, 7(2). 